\title{
CHARACTERIZATION AND STUDY OF IRON(III)-RELEASED FROM ALGINATE/ZEOLITE/FP COMPOSITE
}

\author{
Nia Silvia Sukma, Yateman Arryanto, Sutarno \\ Departemen Kimia, FMIPA, Universitas Gadjah Mada \\ Bulaksumur, Daerah Istimewa Yogyakarta, Indonesia \\ E-mail: niasilvia_chemist@yahoo.com
}

\begin{abstract}
Alginate is an organic polymer that is isolated from brown algae and bacteria, while the zeolite is an aluminosilicate mineral sample. The purpose of this study was to synthesize composite alginate / zeolite / Fe, characterize composite alginate / zeolite / Fe, and assessing the release properties of Fe (III) of the composite alginate / zeolite / Fe. Characterization of the composite is done by observing the color composite macroscopically, and observing the pattern of distribution of zeolite particles in composites using SEM (Scanning Electron Microscope). As for assessing the release of Fe (III) of the composite system made by soaking the composite in a solution of citric acid $0,33 \mathrm{M}$ for nine hours. Components of Fe (III) were dissolved in acid systems were analyzed using UV-Vis spectrophotometer.

The results showed that the composite alginate / zeolite / Fe have colors that are significantly dependent on the component ratio of alginate and zeolitnya. SEM analysis provides information that the zeolites distributed evenly on alginate-Fe phase. The release profile of $\mathrm{Fe}$ (III) of the composite alginate / zeolite / Fe weight variation component alginate produced three mechanisms to increase and decrease the rate of release of $\mathrm{Fe}$ (III). While the release profile of Fe (III) of the composite alginate / zeolite / Fe by weight of the zeolite component generates two mechanisms that increase and decrease the rate of release of Fe (III).
\end{abstract}

Keywords: alginate/zeolite/iron composite, characterization, study of iron release

\begin{abstract}
ABSTRAK
Alginat adalah suatu polimer organik yang diisolasi dari ganggang coklat dan bakteri, sedangkan zeolit merupakan contoh mineral aluminosilikat. Tujuan dari penelitian ini adalah untuk mensintesis komposit alginat/zeolit/Fe, mengkarakterisasi komposit alginat/zeolit/Fe, dan mengkaji sifat pelepasan Fe(III) dari komposit alginat/zeolit/Fe. Karakterisasi komposit dilakukan dengan mengamati warna komposit secara makroskopik, dan mengamati pola distribusi partikel zeolit dalam komposit dengan menggunakan SEM (Scanning Electron Microscope). Sedangkan untuk mengkaji pelepasan Fe(III) dari sistem komposit dilakukan dengan merendam komposit dalam larutan asam sitrat $0,33 \mathrm{M}$ selama sembilan jam. Komponen Fe(III) yang terlarut dalam sistem asam dianalisis dengan menggunakan spektrofotometer UV-Vis.

Hasil pengamatan menunjukkan bahwa komposit alginat/zeolit/Fe memilikiwarnawarna yang signifikan bergantung pada perbandingan komponen alginat dan zeolitnya. Analisis SEM menghasilkan informasi bahwa zeolit terdistribusi secara merata pada fasa alginat-Fe.Profil pelepasan Fe(III) dari komposit alginat/zeolit/Fe dengan variasi berat
\end{abstract}

Characterization and study of iron(III)-released from alginate/zeolite/fe composite (Nia Silvia Sukma, Yateman Arryanto, Sutarno) 
komponen alginat yang bertambah menghasilkan tiga mekanisme dan penurunan laju pelepasan Fe(III). Sedangkan profil pelepasan Fe(III) dari komposit alginat/zeolit/Fe dengan berat komponen zeolit yang bertambah menghasilkan dua mekanisme dan penurunan laju pelepasan Fe(III).

Kata Kunci: komposit alginat/zeolit/Fe, karakterisasi, sifat pelepasan Fe(III)

\section{Pendahuluan}

Tanaman membutuhkan unsurunsur essensial dari dalam tanah. Salah satu unsur essensial yang dibutuhkan tanaman adalah unsur Fe atau besi. Unsur Fe sangat berperan dalam banyak proses fisiologis tanaman (Hochmuth, 2011). Defisiensi Fe pada mempengaruhi proses fotosintesis tanaman (Monsanto, 2010).Sejak tahun 1990-an para peneliti telah melakukan pengembangan pupuk lepas lambat atau slow release fertilizer. Pupuk lepas lambat adalah pupuk yang menyediakan nutrisi bagi tanaman dengan waktu penyediaan lebih lama dibandingkan pupuk konvensional karena pelepasan nutrisi dari dalam pupuk lepas lambat bersifat terkontrol (Trenkel, 2010). Pupuk lepas lambat Fe yang pertama kali disintesis adalah $\alpha$ FeO OH: $\mathrm{MnO}_{2}$ : asam ortofosfor (Bhattacharya et al.,2007). Kemudian Fepolifosfat (Chandra et al., 2009), dan Fe:Mg:P (Singh et al., 2004).

Dalam penelitian ini dilakukan sintesis komposit Alginat/Zeolit/Fe dengan memanfaatkan material yang ketersediannya relatif melimpah di
Indonesia sehingga bernilai ekoniomis. Material yang digunakan sebagai pengemban Fe pada penelitian ini adalah Na-alginat dan zeolit alam. Selain faktor ketersediannya yang tinggi, pemanfaatan Na-alginat dan zeolit alam sebagai material pengemban didasarkan atas sifat alami dari keduanya yang mampu mengikat kation Fe.

\section{Tujuan Penelitian}

Tujuan dari penelitian untuk mensintesis, karakterisasi komposit alginat/zeolit/Fe, dan mengkaji sifat pelepasan $\mathrm{Fe}(\mathrm{III})$ dari komposit alginat/zeolit/Fe

\section{Metode Penelitian}

Alat

Peralatan yang digunakan dalam penelitian ini meliputi peralatan gelas standar, kaca arloji, siring $3 \mathrm{~mL}$, lumpang alu, pH meter, Ball Mill, ayakan 200 mesh, neraca analitik, oven, penggojok, spektrofotometer UV-Vis (Genesys 20). Karakterisasi sampel dilakukan dengan menggunakan SEM (JEOL JED-2300).

Characterization and study of iron(III)-released from alginate/zeolite/fe composite (Nia Silvia Sukma, Yateman Arryanto, Sutarno) 


\section{Bahan}

Bahan-bahan yang digunakan dalam penelitian ini adalahzeolit alam dari Klaten,Na-alginat, serta bahan-bahan kimia produksi Merck dengan kemurnian analisis meliputi, $\mathrm{FeCl}_{3} \cdot 6 \mathrm{H}_{2} \mathrm{O}$ (besi klorida), $\mathrm{C}_{6} \mathrm{H}_{8} \mathrm{O}_{7} \mathrm{H}_{2} \mathrm{O}$ (asam sitrat), $\mathrm{HCl}$ (asam klorida), $\mathrm{KSCN}$ (kalium tiosianat), dan akuades

\section{Prosedur Penelitian}

Zeolit alam berbentuk bongkahan dihancurkan dan dihaluskan dengan Ball Mill serta diayak dengan menggunakan pengayak untuk mendapatkan partikel zeolit berukuran 200 mesh.

\section{Sintesis komposit alginat/zeolit/Fe}

Sebanyak 0,4 g zeolit alam didispersikan dalam $40 \mathrm{~mL}$ akuades $(10 \%$ $\mathrm{b} / \mathrm{v})$ dan $0,4 \mathrm{~g}$ Na-alginat dilarutkan dalam $40 \mathrm{~mL}$ akuades $(10 \% \mathrm{~b} / \mathrm{v})$ dalam wadah yang berbeda.Keduanya kemudian dicampur dan diaduk hingga homogen. Campuran Na-alginat dan zeolit alam dimasukkan ke dalam siring berukuran 3 $\mathrm{mL}$ dan dibentuk menjadi bulatanbulatan. Bulatan-bulatan komposit yang terbentuk diarahkan ke dalam wadah yang berisi $40 \mathrm{~mL} \quad \mathrm{FeCl}_{3} 0,1 \mathrm{M}$ dan direndam selama 24 jam.Setelah direndam selama 24 jam, komposit disaring dan dicuci dengan akuades hingga filtrat hasil cucian memiliki pH 6 -
7. Komposit kemudian dikeringkan dalam oven pada suhu $\pm 60{ }^{\circ} \mathrm{C}$. Komposit alginat/zeolit/Fe disintesis dengan variasi berat alginat dan zeolit seperti yang ditunjukkan Tabel 1.

Tabel 1. Rasio berat Na-alginat terhadap zeolit alam sebagai komponen komposit alginat/zeolit/Fe

\begin{tabular}{|c|c|c|c|}
\hline No & $\begin{array}{l}\text { Na-alginat : } \\
\text { zeolit alam }\end{array}$ & $\begin{array}{l}\text { Na-alginat } \\
\text { (g) } / 40 \mathrm{~mL} \\
\text { air } \\
\end{array}$ & $\begin{array}{l}\text { zeolit (g)/ } \\
40 \mathrm{~mL} \text { air }\end{array}$ \\
\hline 1. & $1: 0$ & 0,4 & 0 \\
\hline 2. & $1: 1$ & 0,4 & 0,4 \\
\hline 3. & $1: 3$ & 0,4 & 1,2 \\
\hline 4. & $1: 5$ & 0,4 & 2,0 \\
\hline 5. & $1: 7$ & 0,4 & 2,8 \\
\hline 6. & $0: 1$ & 0 & 0,4 \\
\hline 7. & $3: 1$ & 1,2 & 0,4 \\
\hline 8. & $5: 1$ & 2,0 & 0,4 \\
\hline 9. & $7: 1$ & 2,8 & 0,4 \\
\hline
\end{tabular}

Uji kualitatif (analisis warna komposit alginat/zeolit/Fe)

Uji kualitatif komposit adalah melakukan pengamatan terhadap warna masing-masing komposit.

\section{Uji kuantitatif (analisis jumlah Fe(III) yang terikat dalam komposit alginat/zeolit/Fe)}

Sebanyak 0,05 g komposit yang telah digerus dimasukkan ke dalam 10 $\mathrm{mL} \mathrm{HCl} 4 \mathrm{M}$ dan digojok selama 3 jam. Sebanyak 0,1 mLfiltrat ditambahkan 2 $\mathrm{mL} \quad \mathrm{KSCN} 1 \mathrm{M}$ dan $1 \mathrm{~mL} \quad \mathrm{HCl} \quad 4 \mathrm{M}$ kemudian diencerkan hingga mencapai $10 \mathrm{~mL}$. Filtrat yang telah dipreparasi kemudian dianalisis absorbansinya

Characterization and study of iron(III)-released from alginate/zeolite/fe composite (Nia Silvia Sukma, Yateman Arryanto, Sutarno) 
dengan menggunakan Spektrofotometer Uv-Vis.

\section{Karakterisasi komposit alginat/ zeolit/Fe dengan menggunakan SEM}

Karakterisasi SEM dilakukan dengan menggunakan SEM JEOL tipe JED-2300. Sampel direkatkan pada wadah sampel, selanjutnya sampel siap dikarakterisasi pada kondsi alat: voltase $=$ $20,0 \mathrm{kV}$ dan piksel $=512 \times 384$.

\section{Pengujian pelepasan $\mathrm{Fe}(\mathrm{III})$ dari komposit alginat/zeolit/Fe}

Sebanyak $0,1 \mathrm{~g}$ masing-masing komposit dimasukkan dalam wadah kemudian ditambahkan $20 \mathrm{~mL}$ asam sitrat 0,33M. Masing-masing sampel digojok selama 9 jam. Sampling dilakukan sebanyak 10 kali pada menit ke- 30, 60, $120,180,240,300,360,420,480$ dan 540 dengan mengambil $2,5 \mathrm{~mL}$ filtrat dari masing-masing sampel kemudian dimasukkan kembali sebanyak 2,5 mL asam sitrat baru ke dalam sampel.Sebanyak $0,1 \mathrm{~mL}$ filtrat hasil sampling kemudian ditambahkan $2 \mathrm{~mL}$ KSCN $1 \mathrm{M}$ dan $1 \mathrm{~mL} \mathrm{HCl} 4 \mathrm{M}$ kemudian diencerkan hingga mencapai $10 \mathrm{~mL}$. Filtrat yang diperoleh kemudian dianalisis dengan menggunakan spektrofotometer UV-Vis.

\section{Pembahasan}

Uji kualitatif (analisis warna komposit alginat/zeolit/Fe)

Alginat dan zeolit memiliki situs aktif yang berpotensi dalam pengikatan Fe(III). Situs aktif yang dimiliki alginat adalah karboksilat (-COO), hidroksil $(\mathrm{OH})$, dan eter (C-O-C) sedangkan situs aktif yang dimiliki zeolit alam adalah muatan negatif pada kerangkanya. Perbedaan jenis situs aktif mengindikasikan perbedaan jumlah Fe(III) yang dapat terlibat dan perbedaan cara pengikatan $\mathrm{Fe}(\mathrm{III})$ pada struktur alginat dan zeolit. Dengan demikian, diasumsikan bahwa penambahan berat alginat atau penambahan berat zeolit pada komposit mempengaruhi jumlah Fe(III) yang terikat dan direfleksikan melalui warna. Gambar 1 merupakan foto komposit alginat/zeolit/Fe variasi penambahan alginat dan variasi penambahan zeolit disajikan pada Gambar 1 dan Gambar 2.

Komposit Fe-zeolit atau komposit 0:1 memiliki warna cokelat kekuningan diindikasikan adanya spesies berupa Fe(III) tunggal terhidrasi yang terikat pada kerangka zeolit(Capek et al., 2005). Komposit Fe-alginat atau komposit 1:0 berwarna hitam diindikasikan mengandung spesies berupa besi oksida

Characterization and study of iron(III)-released from alginate/zeolite/fe composite (Nia Silvia Sukma, Yateman Arryanto, Sutarno) 


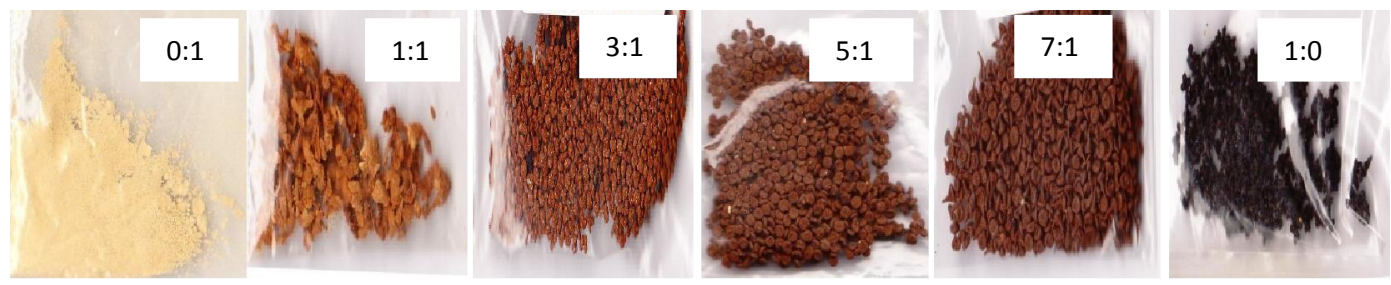

Gambar 1. Foto komposit alginat/zeolit/Fe dengan penambahan rasio berat alginat
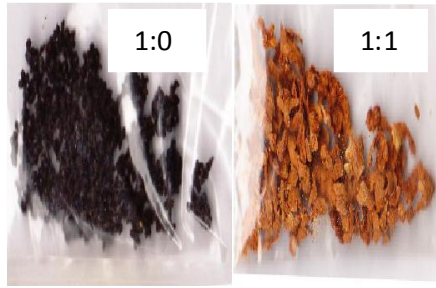

$1: 3$

$1: 5$

$1: 7$

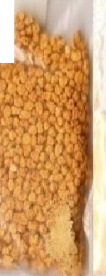

$0: 1$

Gambar 2. Foto komposit alginat/zeolit/Fe dengan penambahan rasio berat alginat

$\left(\mathrm{Fe}_{3} \mathrm{O}_{4}\right)$. Interaksi kation melalui ikatan kovalen koordinasi memudahkan terbentuknya aggregasi logam membentuk partikel-partikel oksida logam berukuran nanometer pada sistem 'egg-box'(Janardhanan et al., 2004).

Komposit dengan variasi penambahan berat alginat menghasilkan warna yang semakin gelap mengindikasikan adanya spesies besi oksida yang mendominasi, sedangkan komposit dengan variasi berat zeolit yang bertambah berwarna semakin muda mengindikasikan adanya spesies $\mathrm{Fe}(\mathrm{III})$ tunggal terhidrasi yang mendominasi.

Selain itu, warna komposit juga dapat merefleksikan kemungkinan jumlah terikatnya kation $\mathrm{Fe}(\mathrm{III})$. Perbedaan warna yang dihasilkan oleh komposit alginat-Fe (1:0) dan zeolit-Fe (0:1) telah mengindikasikan jumlah $\mathrm{Fe}(\mathrm{III})$ yang mampu diikat oleh kedua material. Warna coklat muda dari komposit 0:1 merupakan refleksi dari jumlah Fe(III) yang terikat lebih sedikit dibandingkan dengan jumlah $\mathrm{Fe}(\mathrm{III})$ yang terikat pada komposit 1:0 yang berwarna gelap (kehitaman). Jadi dapat disimpulkan bahwa warna komposit dipengaruhi oleh jenis komponen pembentuk komposit dan rasio komponen didalamnya.

\section{Uji kuantitatif (analisis jumlah Fe(III)yang terikat dalamkomposit alginat/zeolit/Fe)}

Diasumsikan bahwa semakin gelap warna komposit berarti semakin banyak jumlah Fe yang terikat dalam komposit. Warna hitam merupakan identitas dari warna alginat-Fe sehingga

Characterization and study of iron(III)-released from alginate/zeolite/fe composite (Nia Silvia Sukma, Yateman Arryanto, Sutarno) 
diprediksi alginat dalam komposit berkontribusi mengikat lebih banyak $\mathrm{Fe}$ dibandingkan dengan zeolit. Untuk mendapatkan fakta dari asumsi tersebut maka dilakukan kajian lebih lanjut mengenai pengaruh penambahan berat alginat dan pengaruh penambahan berat zeolit terhadap jumlah $\mathrm{Fe}$ yang terkandung dalam komposit. Pada Gambar 3 dan 4 disajikan Jumlah Fe(III) yang terikat pada komposit alginat/zeolit/Fe terhadap variasi penambahan berat alginat dan penambahan berat zeolit.

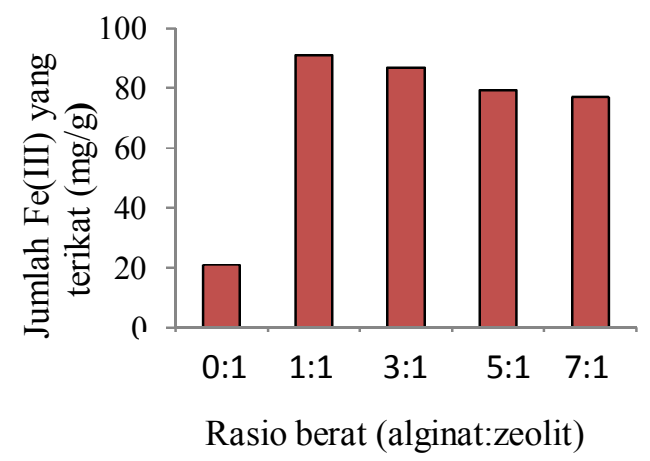

Gambar 3. Grafik pengaruh penambahan berat alginat terhadap jumlah $\mathrm{Fe}(\mathrm{III})$ yang terikat pada komposit alginat/zeolit/Fe

Alginat dan zeolit memiliki kapasitas yang berbeda dalam mengikat kation Fe(III). Alginat mampu mengikat Fe(III) dalam jumlah yang jauh lebih banyak dibandingkan zeolit. Komposit 0:1 atau zeolit-Fe memiliki kapasitas Fe(III) sebesar 20,98 mg/g (Gambar 3), sedangkan komposit 1:0 atau alginat-Fe memiliki kapasitas Fe(III) sebesar 144,77 mg/g (Gambar 4). Perbedaan kapasitas Fe(III) yang terikat pada material pengemban alginat dan zeolit didasarkan atas jumlah dan jenis situs aktif pada masing-masing material.

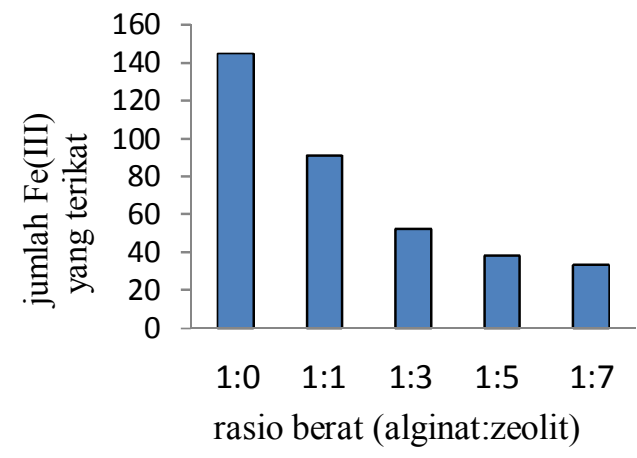

Gambar 4. Grafikpengaruh penambahan berat zeolit terhadap jumlah Fe(III) yang terikat pada komposit alginat/zeolit/Fe

Pada Gambar 3 terlihat bahwa penambahan berat alginat mempengaruhi aktivitas adsorbsi Fe(III) kedalam sistem komposit alginat/zeolit/Fe. Tampak adanya dua fenomena, yaitu pertama meningkatnya jumlah $\mathrm{Fe}(\mathrm{III})$ akibat penambahan alginat dari komposit 0:1 menjadi komposit 1:1 dan yang kedua menurunnya jumlah $\mathrm{Fe}(\mathrm{III})$ akibat penambahan alginat dari komposit 1:1 menjadi 3:1, 5:1, dan 7:1.Diperkirakan interaksi alginat-alginat menjadi faktor utama menurunnya jumlah Fe(III) yang terikat pada komposit. Interaksi alginatalginat adalah interaksi hidrogen antar dan inter polimer alginat, dimana

Characterization and study of iron(III)-released from alginate/zeolite/fe composite (Nia Silvia Sukma, Yateman Arryanto, Sutarno) 
interaksi tersebut terjadi antara gugus

polimer alginate (Chaplin, 2012). Kuantitas polimer yang meningkat mengakibatkan tertutupnya sebagian situs aktif yang tersedia untuk mengikat kation (Pandey, 2007). Menurut Shaviv et al. (1993) dan Unubonah et al. (2008) interaksi antar alginat pada sistem komposit yang berbeda merupakan salah satu faktor menurunnya kapabilitas komposit dalam mengikat kation.

Pada Grafik 4 terlihat bahwa penambahan zeolit mempengaruhi kemampuan komposit dalam mengikat Fe(III). Berat zeolit yang bertambah, menurunkan kapasitas $\mathrm{Fe}(\mathrm{III})$ yang terikat pada komposit secara drastis. Fenomena ini diperkirakan berasal dari adanya interaksi alginat-zeolit.Interaksi alginat-zeolit merupakan interaksi hidrogen dimana gugus hidroksil maupun karboksil pada polimer alginat berinteraksi dengan gugus aluminol maupun silanol pada zeolit. Bertambahnya zeolit menyebabkan jumlah situs aktif pada alginat yang digunakan untuk berinteraksi dengan zeolit menjadi semakin banyak. Atau dengan kata lain, terjadi persaingan antara $\mathrm{Fe}(\mathrm{III})$ dan zeolit untuk berinteraksi dengan alginat. hidroksil dan gugus karboksil pada

Berdasarkan uji kuantitatif diperoleh kesimpulan bahwa alginat mampu mengikat kation $\mathrm{Fe}(\mathrm{III})$ lebih banyak dibandingkan zeolit. Percampuran antara alginat dan zeolit membentuk komposit menghasilkan interaksi alginat- alginat dan alginatzeolit yang berakibat pada berkurangnya kemampuan komposit dalam mengikat Fe(III).

\section{Karakterisasi komposit alginat/zeolit/ Fe menggunakan SEM}

Karakterisasi komposit menggunakan SEM bertujuan untuk mengetahui pola distribusi alginat dan zeolit dalam sistem komposit. Karakterisasi SEM menghasilkan foto tampilan morfologi sampel.Foto-Foto SEM dari masing-masing komposit disajikan pada Gambar 5 dan Gambar 6.

Dari Gambar 5 dapat dilihat bahwa semakin banyak alginat, morfologi permukaan komposit menjadi semakin halus dan bergelombang. 5(a) adalah foto dari partikel-partikel zeolit-Fe yang memiliki morfologi kasar dan berongga.5(b) adalah morfologi dari komposit (alginat:zeolit) 1:1, tampak adanya permukaan kasar dan bergelombang dari komposit. Permukaan

Characterization and study of iron(III)-released from alginate/zeolite/fe composite 
kasar merupakan refleksi dari partikel-

permukaan yang bergelombang partikel zeolit-Fe yang terjebak dalam merupakan refleksi dari interaksi tautan jaringan alginat-Fe, sedangkan silang antara alginat dengan Fe(III).

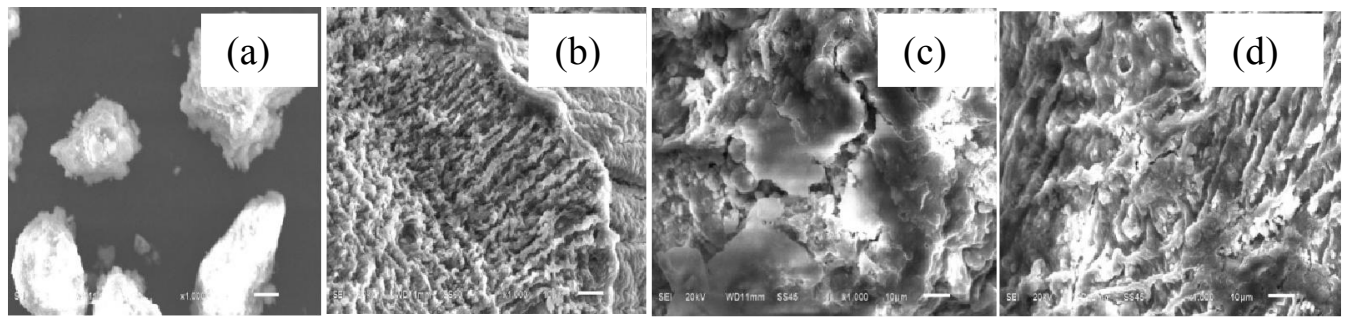

Gambar 5. Foto SEM perbesaran 1000x dari komposit alginat/zeolit/Fe dengan rasio penambahan berat alginat [1:0 (a), 1:1 (b), 3:1 (c), dan 7:1 (d)]

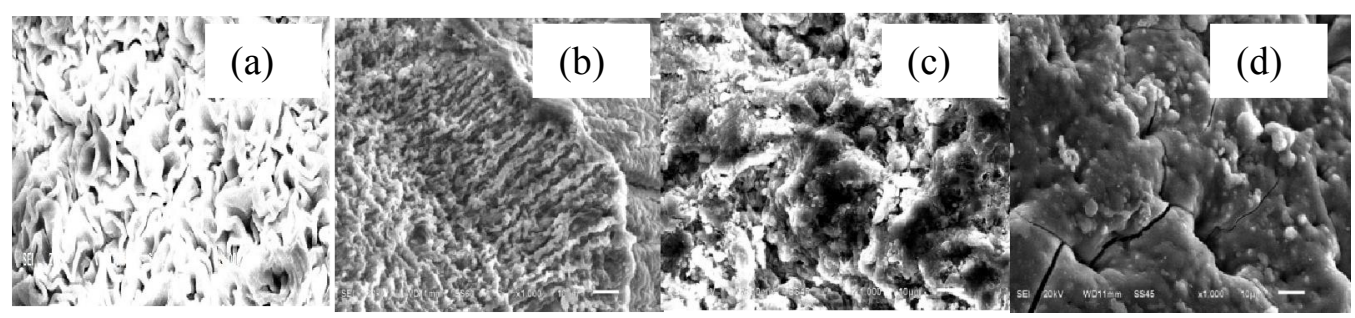

Gambar 6. Foto SEM perbesaran 1000x dari komposit alginat/zeolit/Fe dengan rasio penambahan berat zeolit $[0: 1$ (a), 1:1 (b), 1:3 (c), dan 1:7 (d)]

Pada Gambar 5(c) adalah morfologi dari komposit 3:1 dimana komponen alginatnya lebih banyak dibandingkan komposit5(b). Tampak adanya permukaan yang halus namun tidak bergelombang. Permukaan yang refleksi dari alginat yang membentuk agregasi. Tidak tampak adanya partikel zeolit karena telah tertutupi oleh lapisan alginat yang mendominasi begitu pula dengan komposit 5(d).

Dari Gambar 6 dapat dilihat bahwa semakin banyak jumlah zeolit, permukaan komposit menjadi semakin kasar dan membentuk aggregasi. 6(a) adalah morfologi alginat-Fe tampak halus dan tidak bergelombang merupakan

adanya permukaan bergelombang dan halus. 6(c) adalah foto morfologi dari komposit 1:3 dimana jumlah zeolit lebih banyak dari komposit (b). Tampak adanya permukaan yang kasar akibat partikel zeolit yang terkumpul dan masih terlihat adanya tekstur yang bergelombang berasal dari alginat-Fe. 6(d) adalah morfologi permukaan komposit 1:7.Tampak permukaan yang lebih halus dibandingkan komposit (c) namun tidak sehalus permukaan yang dihasilkan alginat-Fe. Permukaan ini merupakan refleksi dari kumpulan partikel zeolit yang tertutupi oleh lapisan alginat yang tipis. Selain itu, tampak permukaan komposit yang retak Characterization and study of iron(III)-released from alginate/zeolite/fe composite (Nia Silvia Sukma, Yateman Arryanto, Sutarno) 
kemungkinan berasal dari retakan polimer akibat dipanaskan. Hasil analisa SEM pada penelitian ini sejalan dengan hasil penelitian Chmielewská et al.(2011).

Dari kajian hasil karakterisasi komposit dengan SEM dapat disimpulkan bahwa komposit alginat/zeolit/Fe memiliki lapisan alginat pada permukaan komposit. Komposit alginat/zeolit/Fe dengan rasio alginat terhadap zeolit semakin tinggi menghasilkan lapisan alginat yang semakin tebal sedangkan komposit alginat/zeolit/Fe dengan rasio alginat terhadap zeolit semakin rendah menghasilkan lapisan alginat yang semakin tipis.

\section{Kajian Pelepasan Fe(III) dari sistem alginat-Fe dan komposit alginat/zeolit/Fe}

Telah dilakukan uji pelepasan $\mathrm{Fe}(\mathrm{III})$ dari komposit alginat-Fe, alginat/zeolit/Fe dengan variasi penambahan berat alginat dan alginat/zeolit/Fe dengan variasi penambahan berat zeolit. Pada Gambar 7 disajikan grafik pelepasan $\mathrm{Fe}(\mathrm{III})$ dari alginat-Fe.

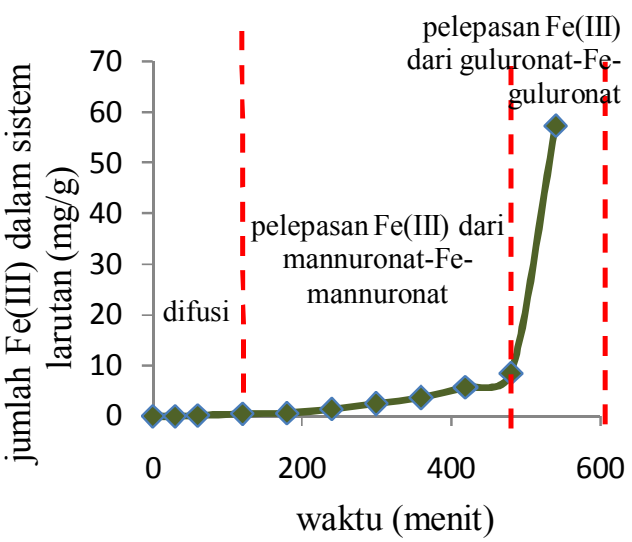

Gambar 7. Grafikpelepasan Fe(III) dari alginat-Fe

Dari Gambar 7 terlihat bahwa pelepasan Fe(III) dari komposit 1:0 atau dari alginat-Fe tampak mengalami tiga mekanisme, yaitu proses difusi, mekanisme lambat dan mekanisme cepat. Proses difusi berlangsung pada menit ke0 hingga menit ke-180. Mekanisme lambat berlangsung pada menit ke-180 hingga menit ke-480 dan mekanisme cepat berlangsung pada menit ke-480 hingga waktu dimana Fe(III) yang terikat pada komposit telah terlepas semua. Mekanisme lambat adalah proses pelepasan $\mathrm{Fe}(\mathrm{III})$ dari sistem dimana jumlah $\mathrm{Fe}(\mathrm{III})$ yang dilepaskan dalam jumlah sedikit secara lambat. Sedangkan mekanisme cepat adalah proses pelepasan Fe(III) dari sistem dimana jumlah Fe(III) yang dilepaskan dalam jumlah yang banyak secara cepat.

Proses difusi adalah proses dimana proton dari asam sitrat berdifusi kedalam sistem komposit dan melepaskan interaksi alginat-alginat antar

Characterization and study of iron(III)-released from alginate/zeolite/fe composite (Nia Silvia Sukma, Yateman Arryanto, Sutarno) 
dan inter-polimer alginat. Interaksi alginat-alginat menyebabkan sifat kerapatan sistem sehingga waktu yang dibutuhkan proton dalam berdifusi bergantung pada banyaknya molekul alginat dalam sistem. Laju pelepasan Fe(III) dari komposit diinterpretasikan melalui kemiringan grafik sehingga interaksi alginat-alginat menjadi penentu laju pelepasan $\mathrm{Fe}(\mathrm{III})$ dari komposit. Mekanisme kedua adalah mekanisme lambat. Mekanisme lambat adalah mekanisme dimana proton yang telah berhasil berdifusi kemudian melepaskan ikatan mannuronat-Fe-mannuronat dengan menukar posisi Fe dengan proton. Ikatan mannuronat-Fe-mannuronat adalah ikatan elektrostatik antara Fe(III) dengan gugus karboksil pada unit mannuronat. Trivalensi kation menyebabkan kation mampu dinetralkan oleh tiga gugus karboksil dari tiga molekul alginat yang berbeda. Mekanisme cepat adalah mekanisme pelepasan $\mathrm{Fe}(\mathrm{III})$ dari ikatan guluronatFe-guluronat. Ikatan yang terbentuk antara kation dengan unit guluronat pada alginat adalah ikatan kovalen koordinasi dimana kation terperangkap dalam suatu klaster dan terikat oleh adanya gugus hidroksil. Fakta ini sesuai dengan hasil penelitian oleh Sartori (1997).
Pemahaman mengenai peran alginat dalam mempengaruhi mekanisme pelepasan $\mathrm{Fe}(\mathrm{III})$ dari komposit alginat/zeolit/Fe dapat diperoleh dengan mengkaji mekanisme pelepasan $\mathrm{Fe}(\mathrm{III})$ dari masing-masing komposit alginat/zeolit/Fe variasi berat alginat. Pada Gambar 8 disajikan grafik pelepasan $\mathrm{Fe}(\mathrm{III})$ dari komposit alginat/zeolit/Fe pada variasi berat alginat.

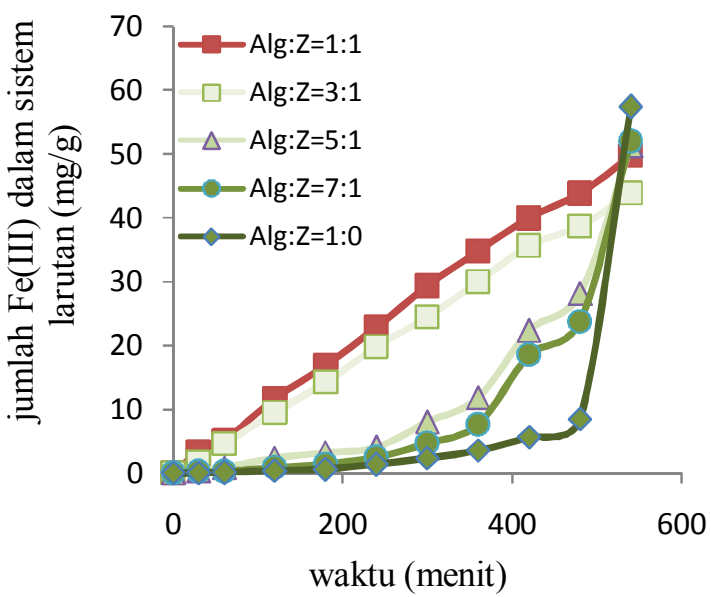

Gambar 8. Grafik pelepasan Fe(III) dari komposit alginat/zeolit/Fe pada rasio alginat terhadap zeolit variasi penambahan berat alginat

Pelepasan Fe(III) dari komposit 1:1 tampaknya memiliki satu mekanisme. Berdasarkan analisis SEM bahwa percampuran antara alginat dan zeolit menghasilkan komposit dimana partikel zeolit bersifat terjebak dalam matriks alginat maka dapat diketahui peran zeolit dalam merubah sifat pelepasan $\mathrm{Fe}(\mathrm{III})$

Characterization and study of iron(III)-released from alginate/zeolite/fe composite (Nia Silvia Sukma, Yateman Arryanto, Sutarno) 
yang terjadi dari komposit 1:0 (alginatFe) menjadi komposit 1:1 adalah hilangnya proses difusi dan mekanisme lambat. Komposit 1:1 dan 3:1 memiliki satu mekanisme dan pelepasan $\mathrm{Fe}(\mathrm{III})$ dari komposit 5:1, 7:1, dan 1:0 memiliki tiga mekanisme. Perbedaan jumlah mekanisme yang terjadi merupakan pengaruh dari komponen alginat dalam komposit alginat/zeolit/Fe.

Jumlah alginat yang bertambah dari komposit 1:1 menjadi komposit 3:1 mengakibatkan menurunnya laju pelepasan $\mathrm{Fe}(\mathrm{III})$ dari komposit tanpa merubah mekanisme pelepasannya. Laju pelepasan $\mathrm{Fe}(\mathrm{III})$ dari komposit diinterpretasikan melalui kemiringan grafik. Jumlah alginat yang bertambah dari komposit 5:1 menjadi 7:1 dan menjadi 1:0 mengakibatkan semakin terlihatnya tiga mekanisme seperti yang dimiliki oleh mekanisme pelepasan Fe(III) dari alginat-Fe. Selain itu, pertambahan alginat juga menurunkan laju pelepasan $\mathrm{Fe}(\mathrm{III})$ dari komposit. Semakin bertambah berat alginat yang berarti bahwa semakin banyak molekul alginat dalam sistem komposit mengakibatkan interaksi alginat-alginat, mannuronat-Fe-mannuronat, dan guluronat-Fe-guluronat semakin meningkat sehingga proses difusi, mekanisme lambat, dan mekanisme cepat menjadi semakin terlihat.

Pemahaman mengenai peran zeolit dalam mempengaruhi mekanisme pelepasan $\mathrm{Fe}(\mathrm{III})$ dari komposit alginat/zeolit/Fe dapat diperoleh dengan mengkaji mekanisme pelepasan Fe(III) dari masing-masing komposit alginat/zeolit/Fe variasi berat zeolit. Telah dilakukan pengujian pelepasan $\mathrm{Fe}(\mathrm{III})$ dari komposit alginat/zeolit/Fe pada variasi berat zeolit dan grafik pelepasannya disajikan pada Gambar 9 .

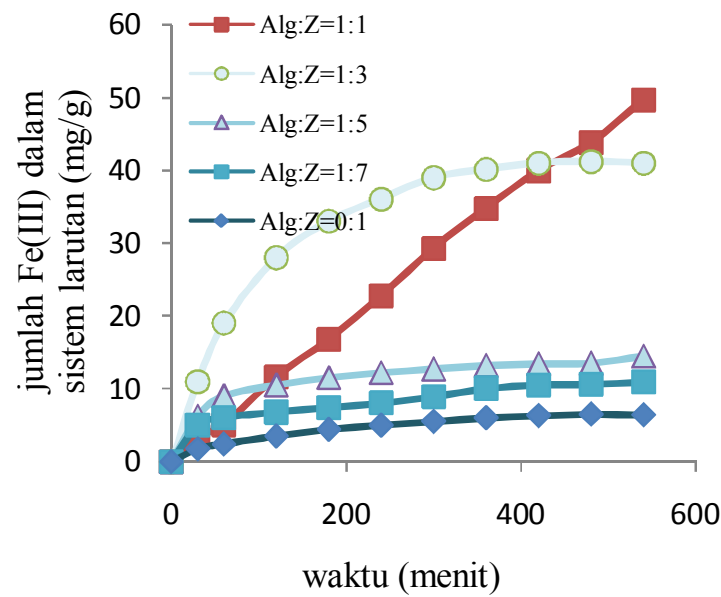

Gambar 9. Grafik laju pelepasan Fe(III) dari komposit alginat/zeolit/ Fe pada rasio alginat terhadap zeolit variasi penambahan berat zeolit

Komposit 0:1 memiliki satu mekanisme pelepasan Fe(III). Satu mekanisme pelepasan Fe(III) yang terjadi pada komposit 0:1 sangat dipengaruhi oleh sifat dan jenis situs aktif sistem. Zeolit adalah suatu partikel kristalin yang

Characterization and study of iron(III)-released from alginate/zeolite/fe composite (Nia Silvia Sukma, Yateman Arryanto, Sutarno) 
sifatnya tidak larut dalam air. Zeolit hanya memiliki satu jenis situs aktif yakni muatan negatif yang dihasilkan dari ikatan Si-O-Al. Muatan negatif pada zeolit menyebabkan kecendrungan bagi zeolit dalam berinteraksi dengan $\mathrm{Fe}(\mathrm{III})$ melalui interaksi elektrostatik. Beda halnya dengan alginat, muatan negatif yang dimiliki zeolit menyebabkan tolakan antar zeolit sehingga ikatan zeolit-Fe menjadi satu-satunya interaksi yang terbentuk.

Pada Gambar 9 tampak bahwa bertambahnya berat zeolit pada komposit dari komposit 1:1 menjadi komposit 1:3 merubah mekanisme pelepasan $\mathrm{Fe}(\mathrm{III})$ dari satu mekanisme menjadi dua mekanisme. Mekanisme pertama adalah mekanisme cepat kemudian dilanjutkan dengan mekanisme lambat. Mekanisme cepat adalah mekanisme pelepasan Fe(III) yang berasal dari ikatan guluronat-Fe-guluronat. Mekanisme pelepasan $\mathrm{Fe}(\mathrm{III})$ yang berasal dari ikatan mannuronat-Fe-mannuronat tidak tampak lagi disebabkan oleh kuantitas partikel zeolit yang lebih banyak sehingga menutupi seluruh akses manuronat dalam mengikat kation Fe. Mekanisme lambat yang terjadi pada komposit 1:3 merupakan pelepasan $\mathrm{Fe}(\mathrm{III})$ yang berasal dari ikatan Fe-zeolit. Fe(III) dari zeolit terlepas setelah Fe(III) dari ikatan
guluronat-Fe-guluronat telah habis. Mekanisme pelepasan $\mathrm{Fe}(\mathrm{III})$ dari komposit 1:3 menjadi komposit 1:5, dan 1:7 tidak mengalami perubahan yang signifikan. Ketiga jenis komposit tersebut memiliki sifat pelepasan $\mathrm{Fe}(\mathrm{III})$ yang sama, yakni didahului oleh mekanisme cepat kemudian diikuti oleh mekanisme lambat. Laju pelepasan $\mathrm{Fe}(\mathrm{III})$ yang semakin menurun seiring dengan bertambahnya berat zeolit disebabkan oleh kuantitas Fe(III) yang terikat pada komposit yang semakin menurun.

Dari penjelasan diatas dapat disimpulkan bahwa interaksi alginatalginat dan interaksi mannuronat-Femannuronat bersifat menurunkan laju pelepasan Fe(III) dari sistem, sedangkan interaksi guluronat-Fe-guluronat bersifat meningkatkan laju pelepasan Fe(III) dari sistem. Keberadaan zeolit berperan sebagai pencegah terbentuknya interaksi alginat-alginat, mannuronat-Femannuronat, dan guluronat-Fe-guluronat.

Aplikasi alginat/zeolit/Fe sebagai komposit pelepas lambat $\mathrm{Fe}$ disesuaikan dengan kebutuhan tanaman akan ketersediaan $\mathrm{Fe}(\mathrm{III})$. Untuk tanaman yang membutuhkan Fe dalam jumlah yang relatif banyak maka diprediksi menggunakan jumlah alginat dengan komposisi lebih dari 50\% sebagai bahan komposit. Sedangkan untuk tanaman

Characterization and study of iron(III)-released from alginate/zeolite/fe composite (Nia Silvia Sukma, Yateman Arryanto, Sutarno) 
yang membutuhkan ketersediaan $\mathrm{Fe}$ dalam jumlah relatif sedikit maka diprediksi menggunakan jumlah zeolit dengan komposisi lebih dari 50\% sebagai bahan komposit.

\section{Kesimpulan}

Komposit alginat/zeolit/Fe memiliki warna-warna yang signifikan bergantung pada rasio komponen alginat dan zeolitnya. Secara mikroskopik, partikel-partikel zeolit terdistribusi pada matriks polimer alginat-Fe. Pelepasan $\mathrm{Fe}(\mathrm{III})$ dari alginat mengalami tiga mekanisme, yaitu mekanisme difusi, mekanisme pelepasan $\mathrm{Fe}(\mathrm{III})$ dari mannuronat-Fe-mannuronat, dan mekanisme pelepasan $\mathrm{Fe}(\mathrm{III})$ dari guluronat-Fe-guluronat. Ikatan alginatalginat dan mannuronat-Fe-mannuronat bersifat menurunkan laju pelepasan Fe(III), sedangkan ikatan guluronat-Feguluronat bersifat meningkatkan laju pelepasan $\mathrm{Fe}(\mathrm{III})$. Zeolit bersifat menurunkan jumlah Fe(III) yang terikat pada komposit alginat/zeolit/Fe. Alginat bersifat meningkatkan jumlah $\mathrm{Fe}(\mathrm{III})$ yang terikat pada komposit alginat/zeolit/Fe.

\section{Daftar Pustaka}

Bhattacharya, I., Bandyopadhyay, S., Varadachari, C., Ghosh, K., 2007. Development of a Novel Slow-
Releasing Iron-Manganese Fertilizer Compound. Ind. Eng. Chem. 46, 2870-2876.

Capek, L., Kreibich, V., Dedecek, J., Grygar, T., Wichterlova, B., Sobalık, Z., Martens, J.A., Brosius, R., Tokarova, V. 2005. Analysis Of $\mathrm{Fe}$ Species In Zeolites By UV-VIS-NIR, IR Spectra And Voltammetry. Effect Of Preparation, Fe Loading And Zeolite Type. Micro. Meso. Materials 80, 279-289.

Chandra, P. K., Ghosh, K., Chandrika, V. 2009. A New Slow-Releasing Iron Fertilizer. Chem. Eng. J. 155, 451-456.

Chaplin, Martin. 2012. Water Structure and Science : Alginate. ARTICLE

Chmielewská, E., Sabová. 2005. Contemporary And Prospects For New Generation Of Environmental Nanocomposed Zeoadsorbents. Petrol. Coal 47 (3), 6-9.

Hochmuth, G. 2011. Iron (Fe) Nutrition of Plants. IFAS extension.SL353.

Janardhanan K., Shrivastava, Y., Nair, B.U. 2004. Studies On the Nature of Interaction of Iron(III) With Alginates. Biochimica et Biophysica Acta 1670, 121- 125.

Monsanto company. 2010. Iron Deficiency Chlorosis in Soybean. Agronomic Alert.

Pandey, A., Bera, D.,Shukla, A., and Ray, L., 2007. Studies on Cr(VI), $\mathrm{Pb}(\mathrm{II})$, and $\mathrm{Cu}(\mathrm{II})$ AdsorptionDesorption Using Calcium Alginate as Biopolymer. Chem.Spec.Bio., 19(1), 17-24.

Characterization and study of iron(III)-released from alginate/zeolite/fe composite (Nia Silvia Sukma, Yateman Arryanto, Sutarno) 
Sartori, C. 1997. The Characterization of Alginate System for Biomedical Application. Thesis of Doctor Philosophy. Department of Materials Engineering, Brunei University

Shaviv, A., Mikkelsen, R.L., 1993. Controlled-Release Fertilizers To Increase Efficiency Of Nutrient Use And Minimize Environmental Degradation - A Review. Fertilizer research 35, 1-12.

Singh, K., Sharma, H.C., Singh, C.S., Singh, Y., Nishizawa, N.K., Mori, S. 2004. Effect Of Polyolefin Resin Coated Slow Release Iron Fertilizer And Its Methods Of Application On Rice Production In Calcareous Soil. Soil Sci. Plant Nutr. 50 (7), 1037-I042.

Trenkel, M.E. 2010. Slow- and Controlled-Release and Stabilized Fertilizers: An Option for Enhancing Nutrient Use Efficiency in Agriculture. International Fertilizer Industry Association, Paris.

Unuabonah, E.I., Adebowale, K.O., OluOwolabi, B.I., Yang, L.Z., Kong, L.X. 2008. Adsorption Of $\mathrm{Pb}$ (II) And Cd (II) From Aqueous Solutions Onto Sodium Tetraborate-Modified Kaolinite Clay: Equilibrium And Thermodynamic Studies. Hydrometallurgy, 93, pp 1-9. 